\title{
Study of euphemistic expression of business English communication in Adaptation Theory Perspective
}

\author{
Liucheng Du \\ Shandong College of Traditional Chinese Medicine \\ Shandong, China
}

\begin{abstract}
In business English euphemistic expression, methods are many and flexible, broader, it can effectively attract customers, promote products, and it is the primary means to seize business opportunities. Therefore, in today's competitive market environment, especially for business people, the flexible use of Business English euphemism method can make you expand even broader customer base, and it becomes an important business language component. Business English is the international business activities in a specific ESP, and it covers a wide range, and has a unique performance of the content and language phenomenon. Therefore, business English and translated more euphemistic expression is the most critical part. Anal size business English euphemism communicative functions as well as business English and translation euphemism.
\end{abstract}

Keywords- Business English; euphemistic expression; translation

\section{INTRODUCTION}

Adaptation Theory is "pragmatic understanding," a book language theory professor Belgian Jef Verschueren is published in 1999. The theory is a new perspective to understand and interpret the pragmatics. According Versehueren perspective, the use of language in the final analysis is "a continuous process of choice of language, whether this choice is conscious, or unconscious, and regardless of the language out of the internal and external reasons" (Versehueren, 1999: 55-56). Conform to the language choice and language is inseparable, the choice of language is the means, and conforming to the language of the purpose and results of the relationship between the two is a dialectical unity. Language users have been able to make the right choice in a variety of language, because the language has variability, negotiability and adaptability which are three characteristics. Compliance language refers flexible language that can let users choose from a project, and ultimately achieving the desired communicative purposes. Therefore, we ensure the smooth progress of the language of communication between the translation and translation activities audiences while ensuring consistency of translations and original advertising effectiveness, advertising translation should conform to local culture, reflect the cultural essence. The use of language as a social behavior and human life cognitive, social, and cultural factors are closely related. So pragmatics should be from cognitive, social, and comprehensive perspective of cultural phenomena of language study overview. He believes that people use language is the process where a communicative person achieves communicative purposes at different levels of consciousness and continues to make the process of language choice. Language selector has been able to use the language in a process of continuous choice, because language has variability, negotiability and adaptability, the use of language is from the following four aspects to describe and explain: follow contextual relations, conform to the language structure, the degree of dynamic and adapt to the process of consciousness compliant. These four aspects are pragmatic methodology in a continuum. Conforming and adapting to the context of the relationship between language structures conform to the provisions of the range, and that is comprehensive linguistic factors and verbal communication and nonverbal factors. Language expression is a dynamic process, in this process because people have different languages to follow the degree of awareness changes in the structure of the relationship between context and language.

Along with China's reform and opening up and accelerating global economic integration process of deepening international business relations between China and the world, it has been an unprecedented development. English language is an important tool for international business activities, including trade business English business language in business, contract agreements, legal language, commercial advertising promotional language, and so on More common in English speaking, business English has its own special style, the usual format, vocabulary and expressions, warm and friendly hospitality, tactful polite discourse, and carefully worded properly close correspondence in stark terms the characteristics of business English. In order to establish a corporate image as perfect as possible, we are to maximize the customer trust and satisfaction. Business professionals both in correspondence textual representation, or in a business negotiation negotiations, often use means of euphemisms and tactful way to express polite, reserved and dignified state their views or wishes, requests or suggestions to create a good atmosphere, parties to the transaction are in order to achieve their intended purpose. Euphemism and Euphemism in Business English is widely used, involving almost every aspect of the various areas of business activity and transaction processes. In international trade, for example, from the beginning of the establishment of trade relations inquiries, offer, counteroffer, 
pricing to shipping, insurance, loan payments, the complaint claims, etc., will use a lot of euphemistic expression.

\section{CONFORM TO THE SOCIAL WORLD}

Euphemisms conform social world is a dynamic process, and it is relatively complex and subtle. Every culture has its own norms and values reflected in the pragmatics, we select the language that everyone in the community and the social world are associated surrounded by different cultures and it is certainly the most familiar culture of their country, but at the same time, you also belong to other cultural groups or races, or even religious, or a job. Language has its unique customs in fact, the language adapted to the social world is very common in the business of communication, the euphemism is one of the effective selection methods in order to achieve specific communicative purpose of using the social world which is mainly reflected in the response to cultural differences and cultural differences and practices conforming to social aspects, and it is a direct impact on your ability to send or receive business letters, which of course includes the use of euphemisms when you are in a different cultural backgrounds to communicate, whether by letter or orally in the form of letters and telegrams, you are in accordance with their own culture. However, the use of euphemisms letter recipient or by the speaker will be understood according to their own culture so it is easy to misunderstand the cultural differences, which is one of the factors of influence communication, therefore, in the business of communication in the choice of euphemism, we need taking into account cultural differences.

With the development of economic globalization, economic and cultural exchanges between the countries of the world have become more frequently, and business English translation between enterprises in different countries is as a means of communication and media in the communication plays a crucial role. Business people in business meetings are often euphemistic. With expectations and expression as an important rhetorical device, it can subtlety, politely expresses their views and opinions, requests and recommendations to the customer, in order to effectively achieve the intended trading purpose.

\section{EUPHEMISM FUNCTION}

\section{A. Taboo Function}

Because the human fear certain things or phenomena and do not want to speak at the language, but sometimes they have to express some kind of meaning, so people will learn to use euphemisms. For example, every nation in the "dead" argument has its own euphemism. English-speaking people of the country and many nations taboo direct saying. English "death also has a variety of forms of expression. People often" go "(topassaway)," parting people "(todepart)," last sleep "(finasleep), rest in peace (tohavefoundrest) say the words instead of saying someone "Dead" (todie).

\section{B. Politeness}

Another function is to avoid euphemisms presumptuous and indecent assault in communication, when forced to be involved in something unpleasant, euphemistic expressions should be chosen in order to avoid hurting each other's feelings. When socializing, people always pay attention to courtesy, to avoid indecent words and deeds. Use euphemisms, talking not only seem polite but also take care of each other's feelings and it can often get each other's goodwill and recognition. As seen English (US) country woman, beginning to use the old word does not seem good, often prompting ignore each other, so some euphemism came into being, such as: the-longer1Mng (older people), etc. instead of "old age" (elderly, seniors) and "se-nility" (senile) and so on.

\section{Hide Function}

In some political activities, there is emergence of a number of diplomatic euphemism. Diplomas are the main users of such diplomatic euphemism. Because they often attempt to shorten the severity of international tension to a minimum, thus making their real motives give a vague impression. Works of English majors in interpreting skills are learned while interpreters should have a strategy to adapt to the dynamic process of interpretation, how to cultivate skills in cross-cultural awareness is still relatively absent. In addition, low student achievement and high interpreters interpreting student achievement in the use of dynamic response to no significant differences in the frequency of consciousness and theory, cross-cultural awareness still need to be improved, and we need to strengthen the training efforts.

\section{AdVICE TO ENGLISH TEACHING BUSINESS ENGLISH INTERPRETERS IN UNIVERSITY}

Teaching Business English Interpretation students must conform to the idea, adapt to changing cultural context, dynamically adapt to the culture and customs of the target language, and match up, to make concessions on the pragmatic and responsive manner. Conform to the audience psychological and cultural background, take domesticating translation strategy. Be aware that the other party will be in the position to say how to make a party to understand the other party.

In the actual teaching business English interpretation, we can make use of audio-visual materials related to the field of interpretation, interpretation of the relevant business experts movie clips, or Zhu Tong Zhang Lu and other theories and appreciation, case studies and simulation and other teaching methods to improve students' language levels, and improve cross-cultural awareness of their business English interpreters. Through case studies students can exercise critical thinking skills to analyze why the judge is correct, why is wrong; to improve students' combat capabilities through simulation, to experience and practice acquisition of Business English interpretation skills. Encourage multidisciplinary mastery, for example, the Business Etiquette, Business English Lessons and interpreting visual lesson about the content of culture are combined to pass on. Teach the students some practical coping tactics to deal with crosscultural communication problems encountered, such as: the target language borrowed ready audience (addressee) 
familiar expressions to replace primitive information; literal translation plus comments; interpretation strategy. Instill students with different ethnic culture, business culture, a different view of the world, different values and ways of thinking, different cultural customs and taboos. Conducting business in English interpreter for the culture shock may be encountered symposia, and role-playing and teaching tasks, which allow students to experience the true meaning of helping students in the future business English interpretation of actual combat, and build a good cross-cultural bridges, and play good "cultural ambassador" role.

\section{MODE OF BUSINESS ENGLISH EUPHEMISM EXPRESSION}

Business English euphemism not only transmits information, and more importantly, through the process of transmission of information it can influence each other to make the appropriate response. This is consistent with what Halliday said: interpersonal function of language is to make the language functions as a party to influence attitudes and behavior of other attitudes and behavior. In practice business communication, flexible use of euphemism, not only can be achieved through alternative vocabulary, but also can achieve the aspirations of the integrated use of euphemism and can change the form of grammatical tense, voice, tone, etc.

Lexical substitution means euphemistic vocabulary and refers to sweet words that do not hurt each other face to ease relations merchants and customers. Business English Central Standing Committee met stiff directly replace those words with euphemistic words, especially those prone to cause unhappiness or cause improper discrimination argument, that expression seems sweet elegant. Retrogression state law, in Business meetings and correspondence in terms of foreign trade, if the form of the verb is into the past tense to express the appropriate inquiry, request or even objected, pointing out that the other party negligence and other means, it appears that the language of euphemism, humble attitude, they are able to safeguard their own interests while avoiding embarrassment trading partners, which will help build longterm stable and smooth trade relations between the two sides of the negotiations. Passive method, English active voice is to emphasize that executive action, and the passive voice is to emphasize the action of the bearer. In Business English common initiative tense bilateral trade bluntly express opinions and ideas, if an order or request, suggestions or criticism occur with the passive voice is to avoid direct contact with each other, emphasize the contract, promise or agreement provisions the duties and responsibilities of work, in order to avoid abrupt impolite tone to avoid being too stiff to reach both sides preservation of rights and responsibilities, it is more in line with international business practices.

\section{CONCLUSIONS}

Euphemism expression used in different business activities played an invaluable role in different contexts. In English consultation business negotiations, due to the different negotiating, what, when, where, and atmosphere, etc., there are some things not directly say it, you need to take tactful, subtle expression to ease tense atmosphere of the talks or avoid intensification of contradictions and conflicts. Euphemism application form English is in a variety of business, flexible approach, the speaker should be able to be flexible in this euphemism pragmatic strategy, as well as the emotional needs of both sides of the transaction were polite, respectable psychological needs and other factors make transaction carry on friendly and smoothly.

\section{Reference}

[1] Weiya Ting. Adaptation Research perspectives in business English communication euphemistic expression[D]. Shanxi University of Finance,2010.

[2] Xion Li. On the application of the principle of euphemistic expression in response to business communication [J] intelligence, 2014,08: 270 +273 .

[3] Wang Na. Business English euphemism and Translation [J] modern commerce industry, 2010,09: 234-235.

[4] Mao Zhongxia. Business English euphemistic expressions and translations [J] Changsha Social Work College, 2007,02: 80-82.

[5] Wang Hengen. Euphemism in Business English Letters [J] Henan University of Science and Technology (Social Sciences), 2009,02: 57-59.

[6] Zheng Erqi. Business English euphemism and translation [J] Xuchang University, 2003,03: 81-82.

[7] Su Rina. Business English in euphemistic expressions [J] ACADEMIC JOURNAL (Natural Science), 2005,02: 126-128. 